\title{
Migration from Historic Mission Churches to Pentecostal and Charismatic Churches in Ghana
}

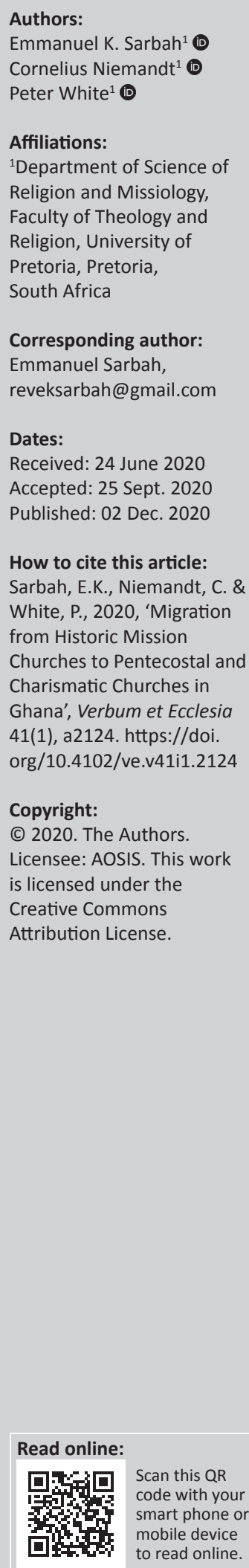

The advent of Pentecostal and Charismatic Churches (PCCs) in Ghana since the early 20th century has significantly impacted its religious landscape. Migration of members from the Church has become a great source of worry for the leadership of the Presbyterian Church of Ghana (PCG), a Historic Mission Church which is 191 years old with less than one million members. This article discusses factors for migration of members from Historic Mission Churches (HMCs) to PCCs with reference to the Presbyterian Church of Ghana (PCG). This requires that Historic Mission Churches should train laity to become the active components of the Church. Also, baptismal candidates should be given the option to choose the type of baptism they prefer to resolve the issue of members migrating to PCCs to seek baptism or rebaptism by immersion.

Intradisciplinary and/or interdisciplinary implications: The article contributes to the interdisciplinary dialogue on mission and church growth, with emphasis on migration. It provides missiological implication and reflection on the missional vocation of the church.

Keywords: Historic Mission Churches; Pentecostal and Charismatic Churches; African Initiated Churches; push and pull factors; migration; biological; pastoral; laity.

\section{Introduction}

Migration of members from Historic Mission Churches (HMCs) to Pentecostal and Charismatic Churches (PCCs) in the Ghanaian religious landscape is partly because of the rise of African Initiated Churches (AICs) and subsequently PCCs in Ghana in the early 20th century when a deliberate attempt was made by the missionaries to impose their culture on the African Christian, which created a religio-cultural gap. The rise of PCCs, influenced by the activities of William Wade Harris, a Grebo from Liberia, led to the gradual decline of the HMCs (Anderson 2004:1; Asamoah-Gyadu 2005a:14, 33, 39; Omenyo 2006:94).

Most Christians, including leaders encountered in PCCs in Ghana in urban, semi-urban and rural areas were members of HMCs. Various reasons account for this trend, which has become a great source of worry for the leadership of HMCs. This study investigates and identifies the 'push' and 'pull' factors attributable to this, with focus on the Dangme-Tongu and Ga Presbyteries of the Presbyterian Church of Ghana (PCG).

The objectives set out in this article are to explore the general trend of migration from HMCs to PCCs, identify the factors contributing to the migration of members from PCG to PCCs, analyse the impact of migration on PCG whilst recommending a pastoral and laity response to the phenomenon of migration.

The research used literature study, quantitative and qualitative research approaches and observations as tools for data gathering whilst the issues were discussed thematically. Primary data were collected from questionnaires and interviews with significant individuals such as pastors, leaders and members from selected HMCs and PCCs in Ga and Dangme-Tongu Presbyteries, including those who have migrated. In all, 220 questionnaires were administered within the two Presbyteries between April and June 2019. A total of 190 questionnaires were retrieved and used for the statistical analysis under various subheadings.

\section{Migration}

Growing up in PCG, I witnessed the enthusiasm of members and the pride they took in belonging to the Church. Four major experiences motivated me to undertake this research on HMCs in Ghana in the light of migration of their members to PCCs. Firstly, as a member of the district 
evangelism team at Odumase-Krobo in the Eastern region of Ghana, I observed that during house-to-house evangelism, most people we came across in the community told us they were Presbyterians but had then become members of one of the PCCs. Secondly, my experience as a minister of PCG in charge of four congregations from 2009 to 2018 across three political regions, namely Volta, Eastern and Greater Accra, also gave me some insight into this changing trend. My regular visitations to members whose names were in the roll book but not in Church showed that most of them had joined other PCCs.

Thirdly, when I served as the Mission and Evangelism Coordinator in the Sokpoe District of the Dangme-Tongu Presbytery from 2010 to 2014, during our evangelistic activities in urban, semi-urban and rural areas, we came across Presbyterians who had joined other PCCs because there was not a Presbyterian Church in these communities. Fourthly, my studies in Urban Mission and Christianity in the non-Western World at Trinity Theological Seminary revealed the phenomenon of people leaving the Church through the back door. It seems the rate of loss because of this, outweighs the gains in terms of new members coming through the front door.

Furthermore, my recent visit to a South African Presbyterian Church in Pretoria revealed this worrying trend as captured in a report read to the congregation by the session clerk at the annual congregational meeting held on 19 August 2018 in which he lamented on a decrease in the youth and children's ministry membership. According to Krejcir and Johnson (2018), between 1990 and 2000, Reform congregations in the United States of America declined by almost five million members and the Rt. Rev. J.O.Y Mante in his first address to the general assembly of the PCG as moderator at Ramseyer training centre Abetifi Kwahu held from 16 to 22 August 2019. In his address, he admonished PCG to put its house in order, to avoid this trend as observed in reformed congregations in the United States of America.

\section{Types of migration}

There are five identifiable types of migration, such as human migration, animal migration, forced migration, voluntary migration and reluctant migration (Teevan \& Hewitt 1998:433-434). In religion, migration occurs in various forms such as:

- Intra-church migration: migration within the same denomination, for instance, from PCG, Grace Congregation - Akropong to PCG Trinity Congregation, Kwashiemen

- Inter-faith migration: migration from one faith to the other, for instance, from Christianity to Islam, from Islam to Christianity or from Judaism to Christianity

- Inter-denominational migration: migration from one denomination to the other - usually voluntary - for instance, from PCG to ICGC. This is the focus of the article
Voluntary migration hinges on an individual's free will and initiative, which involves weighing options and choices by analysing the 'push' and 'pull' factors of two locations before making their decision. The 'push' factors signify undesirable or unfavourable conditions at the place of origin, whilst the 'pull' factors, on the other hand, refer to desirable or favourable conditions in an external location. What it means is that members do not move from HMCs to PCCs unless they are induced to do so by some internal or external force (Teevan \& Hewitt 1998:433). The desire to live in a better place is usually the motivating factor that influences people to migrate voluntarily. Wherever there are pull factors, be it social, economic and spiritual, people are normally attracted to them

\section{Overview of Christian mission in Ghana: Special reference to historical mission and Pentecostal and Charismatic Churches}

This part of the research highlights the history, mission achievements of Ga and Dangme-Tongu Presbyteries of the PCG (Ga and Dangme-Tongu are located in the Greater Accra and Eastern regions of Ghana, where Ga and Dangme dialects are spoken, respectively) the contributions of the Basel and Scottish Missions and Africans towards the growth of these two Presbyteries and an introductory overview of the so-called HMCs and their achievements. It further gives a synopsis of Pentecostal and Charismatic movements; their historical antecedents in Ghana, impact on the Ghanaian religious landscape and the society at large whilst drawing relevant conclusions.

\section{Ga Presbytery}

The Ga-Dangme Presbytery as it used to be called, was amongst the first five presbyteries created by Synod of the PCG in 1922 to enhance effective administration of the Church. It is sandwiched between Dangme-Tongu, Akwapem and Central Presbyteries.

The first Basel missionaries arrived at Osu on 18 December 1828 with Frederick Noi Dowuona, the son of an Osu Mantse (chief) who later served as an able interpreter and the assistant teacher in the castle school. Osu is, therefore, the starting point for any historical narrative about institutional Christianity in the Gold Coast. These first missionaries made almost no impact because the unwholesome practices employed by many Europeans created a negative image about them amongst the natives on the Coast. At the same time, most of them also died of Malaria (Ga Presbytery 2012:9; Hildebrandt 1981:91-92).

In order to learn their language and culture, the second batch of missionaries who arrived in 1832, rented a house at Osu and lived amongst the indigenous people, but soon suffered a similar fate (non-acceptance) amongst the indigenes. Indeed, this was a good strategy adopted by the missionaries 
by living amongst them. This singular act, as demonstrated by the missionaries would have sent a clear message to the people to have considered them as one of their own, hence, could easily relate to them. However, the negative behaviour portrayed by other European traders affected their otherwise well-intentioned goal of evangelisation.

The Basel Mission work at Osu and its adjoining communities were, however, boosted by the arrival of lay African Christians from Jamaica in 1843 coupled with the involvement of indigenes such as John Anum and Moses Lomo who were the first Osu citizens to be baptised (Ga Presbytery 2012:9, 11).

Subsequently, the first indigenous Christian community in the Ga area was planted by George Thompson and his wife Catherine Mulgrave. They were amongst the Basel Mission team that arrived from Jamaica in 1843. The first batch of the boys' school (present-day Osu Salem Junior High School) included George Lomotey, Godfred Alema Dowuona (later Osu Mantse 1887-1897). Six other boys who had been instructed in Thompson's school became the nucleus of the Seminary, which was established in Osu in 1850, which was later absorbed into the Akropong Seminary in 1856 (Ga Presbytery 2012:7-9; Smith 1996:56-57).

The arrival of Johannes Zimmerman in 1850 at Osu took the evangelisation in the Ga and Dangme areas to new heights. Having produced a Ga Grammar book and dictionary, translated; the bible into $\mathrm{Ga}$ (the first in any Ghanaian language), Luther's Shorter Catechism as well as the Wurttemberg Confirmation Book, he moved to establish a Christian cottage at Abokobi, where a traditional priest Paolo Mohenu was later converted (Ga Presbytery 2012:12).

\section{Achievements of Ga Presbytery}

The achievements of Ga Presbytery include the establishment of Salem Community, a music school, a Wafer production and sales enterprise, Moriah prayer Garden at Danfa. The Presbytery also has a Market and Prisons Ministry, introduced Northern Outreach Programme, a Radio Ministry in Ga, Twi and Hausa and the Dorcas Ministry to commercial sex workers. Ga Presbytery currently operates a microfinance service, which has helped to increase its financial base. There are currently 134297 Presbyterians in the Ga Presbytery (Ga Presbytery 2012:14; PCG Statistics 2018:8-9, 33).

\section{Dangme-Tongu Presbytery}

Dangme-Tongu Presbytery shares a border with three political regions in Ghana, namely Volta, Eastern and Greater Accra. In 1851, Rev. Johannes Zimmermann's evangelistic activities led him to Odumase-Krobo, following his arrival in the Gold Coast in 1850 as one of the pioneering missionaries. He was warmly received by the then Chief, Nene Odonkor Azu who subsequently gave three of his sons to be baptised into the Christian faith and educated. They became the first Christians and scholars in Kroboland who helped to establish several congregations in the Odumase district (Dangme-Tongu Presbytery 1972-2012:2-5).

As a result of rapid expansion of PCG in both Ga and Dangme areas and the need to develop the Dangme language and enhance new methods of evangelism suitable for their largely rural conditions, Dangme-Tongu Presbytery was carved out of Ga and Dangme Presbytery in 1972 (Dangme-Tongu Presbytery 1972-2012:13).

The church, school and the creation of Christian quarters became the means of evangelising and nurturing new members in Dangme and Tongu lands. Consequently, in 1863, two citizens of Ada, Daniel Narh and Andrews Teye were baptised in Krobo Odumase, thus, were instrumental in helping to establish congregations in the Ada district. Moreover, Christian Dzihorlu Lanyo Ahadzi, a native merchant from Tefle in the Tongu areas was baptised and trained as a catechist by Zimmermann between 1860 and 1865. After his training, he established congregations at Sokpoe and Tefle in 1877 and 1890, respectively (DangmeTongu Presbytery 1972-2012:10).

A major challenge faced by the new Presbytery was the lack of adequate personnel on both the lay and the ordained fronts. Consequently, the Zimmermann scholarship scheme was instituted in 1972 to identify and sponsor suitable persons at Trinity College for the ordained ministry. The first beneficiaries of this scheme were Messrs D.N.A. Kpobi and B.Y. Quashie who entered Trinity College in September 1972, followed by Mr G.N.A. Okraku. In addition, four experienced laypersons were given 'field Ordination' in 1974 to augment the pastoral staff of the Presbytery. These were Revd. E.N.L. Jones, J.L. Adzei, J.T. Odonkor and A.A. Amuah (Ga Presbytery 2012:7-9).

\section{Achievements of Dangme-Tongu Presbytery}

The result of missionary activities in Dangme-Tongu Presbytery was that Christian cottages called 'Salem' were built for people who were disowned by their families for converting to Christianity thus, refused to perform dipo - a traditional puberty rite for girls. Even though the Salem system served a purpose, it affected family bonding. In order to build its economic fortunes, the Presbytery has constructed a guest house, engaged in mango plantation and a cattle ranch. It currently has 16 districts with 42304 memberships (Dangme-Tongu Presbytery 1972-2012:12, 15-16; PCG Statistics 2018:8-9, 18). In general, the Presbytery has contributed tremendously to the religious, educational, health and economic life of the Dangme and Tongu areas.

\section{Historic Mission Churches}

By the length of their existence in Ghana, spanning over 100 years, some scholars prefer to call these Churches 'Historic' (Hildebrandt 1981:156; Kpobi 1999:7). Some of these HMCs include Methodist Church Ghana, PCG, the Evangelical PCG, the Roman Catholic Church, the Anglican 
Church, American Methodist Episcopal Church (A.M.E Zion), the Baptist Church, the Salvation Army and the Seventh Day Adventists Church (Foli 2001:7).

One distinguishing feature of HMCs is clearly defined administrative structures that take care of their congregations all over the country. In order to ensure the coordination of all activities, they have committees and departments at the regional, district and congregational levels (Foli 2001:7). Leadership at both national and regional levels are mostly elected with specified tenure of office, whilst the district and local leadership are appointments by the elected officers (Foli 2001:9).

Membership in HMCs is generally 'biological'11 (Foli 2001:10). Once a child is born, he or she is baptised and automatically becomes a member of the parent's church. This practice means that continuous membership in HMCs is assured.

\section{Pentecostalism}

The traditional Pentecostal movement, which started in Azusa street, Los Angeles, United States of America in 1906 emerged on the Ghanaian ecclesiastical landscape in the 1920s. Pentecostalism in Ghana can also be traced to the Faith Tabernacle Church known as the Christ Apostolic Church associated with Apostle Anim who is generally regarded as the 'father of Pentecostalism' in Ghana (Omenyo 2006:94). Atiemo (1993:20-21) posited that in 1927, some Ghanaians, including Apostle Anim, were deemed to have been baptised in the Holy Spirit, which led to the formation of a Christian movement. Since the early part of the 20th century, the growth of Pentecostal and Charismatic movements has been dramatic and a force to reckon with. They have made both qualitative and quantitative impact on the Ghanaian religious and political landscape (Asamoah-Gyadu 2005a:xi, 4; Conner 2011:103-104).

Scholars have varied opinions regarding the factors that led to the rise of the Pentecostal and Charismatic movements, particularly in Ghana and in Africa as a whole. It has generally been attributed to the quest by the African to attain independence and self-expression from European missionaries and colonialists and mission churches inability to recognise African culture and tradition, which identified them as African Christians in their worship service. For Bosch (1991:352-353, 393-399), it was a paradigm shift from traditional models of mission, whereby the main concern was for the salvation of converts from eternal condemnation with little interest in the condition of the people so converted to 'experiential religion', which involves termination of poverty, discrimination, illness, demon possession, sin, attention to human welfare and the moral improvement of humanity.

Furthermore, some of the existing HMCs were sceptical of the charisma of leaders of these movements and were not prepared to work with them. Consequently, they established churches independent of the mainline churches in order to have the freedom to operate on their own. There was perceived lack of dynamic manifestation of the Spirit of God in the mainline churches, poor pastoral care, whilst spiritual issues that confronted members were ignored or unattended to (Omenyo 2006:73, 98).

The phenomenon was also primarily because of the search for relevance and a fresh voice by the African Christian (Sanneh 2008:279). As Bediako rightly puts it 'Christian identity is an essential ingredient that results in a clearly defined theological interest' (Bediako 1999:xv). From the aforementioned, one can conclude that the African Christian was seeking for the relevance of the scripture in his or her day to day life and a fresh voice to speak to their existential needs. Moreover, the leaders spoke in a language that member could identify with (White \& Neimandt 2015:250). This is what the Pentecostal and Charismatic movements seek to offer its adherents. Thus, Christianity is not only about the supernatural, but the socio-economic issues affecting the world. The Pentecostal and Charismatic movements in Ghana have made a religious, and socioeconomic impact in Ghana as discussed here.

\section{The impact of Pentecostal and Charismatic Churches in Ghana}

\section{The religious impact}

Religion is a central part of Ghanaian society; therefore, everything is explained from the religious point of view, which influences the general demeanour of most Ghanaians. Areas where Pentecostal and Charismatic movements have impacted include an expression of personal faith, evangelism, emphasis on existential needs, renewal in mainline churches, liturgy, ministry, Christian education and on Ghanaian society (Deji \& Ishola 1999:150-153).

\section{An expression of personal faith in Christ}

Asamaoh-Gyadu (1997) posited that another impact Pentecostal and Charismatic movements have made on the Ghanaian religious landscape,

$[I] \mathrm{s}$ the shift from people identifying themselves with the Christian faith based on having been baptised into it by their parents or guardian, and enrolling into church membership by merely producing infant baptismal certificate and learning by rote, church creeds recited during confirmations, to faith-based on deliberate choice. (p. 179)

Thus, he emphasises the need for Christians to have personal encounter with the Lord as it happened in the life of Apostle Paul in Acts 9:1ff.

\section{Renewal in mainline churches}

The rise of PCCs has challenged orthodoxy in Africa (Pobee \& Ositule II 1998:10). It has brought renewal into HMCs elements of spirituality, which were formerly found amongst 
the Pentecostal and spiritual type of churches in terms of evangelism, liturgy, ministry, fellowship, commitment, Christian education, indigenisation, lay participation and therapeutic value. Through the renewal groups in HMCs, most members have experienced conversion and the baptism of the Holy Spirit with its attendant manifestation of charismata and have become very committed (Atiemo 1993:36-45; Omenyo 2006:76).

\section{Evangelism}

The Pentecostal and Charismatic Churches in Ghana have impacted the evangelistic zeal of most churches as members engage more in evangelism through street and house to house and the use of mass media in the power of the Holy Spirit. The Pentecostal and Charismatic Churches endeavour to establish a link between everyday work and the faith of members. Thus, it is emphasised that spiritual gifts are not an end in themselves but a means to an end.

The new convert classes are taken seriously, where members are taught that, as a sign of responsible church membership, one must put his or her resources (human and material) at God's disposal through the payment of tithe, offerings and by seed sowing (Asamoah-Gyadu 1997:183).

\section{Emphasis on existential needs}

The ordinary Ghanaian belief in spiritual forces, such as witchcraft, fetishism, ancestral spirit, as well as the supernatural cause of misfortunes, such as sicknesses, setbacks, childlessness and other life-related problems. Hence, the ordinary Ghanaian seeks answers to these existential questions from a religious-theological context (Asamoah-Gyadu 2002:17, 2005a:1). The Pentecostal and Charismatic Churches speak to the fears and trials of Christians thereby providing protection from evil forces by making it mandatory and possible for members to have the power of the Holy Spirit through faith in Jesus Christ, thus leading to personal transformation (Anderson 2004:405-406). The Holy Spirit is indispensable in the life of the Christian. He is believed to bring transformation in the total being of the individual Christian and society through prayer, fasting and miracles, amongst others. Therefore, during sermons and prayer sessions, more time is spent on praying for members against demonic powers in the power of the Holy Spirit.

\section{Liturgy}

In the African Pentecostal Christian thought, worship is a moment of divine encounter, inspiration, transformation and healing (Asamoah-Gyadu 2005b:23) The success of PCCs in Africa and Ghana in particular is largely because they provide contextualised Christianity, fulfilled African religious aspirations and the use of African style of worship and liturgy (Anderson 2004:122). White (2017) observed:

During the colonised era the activities of the European mission churches appear to culturally colonise the spirituality and worldview of the Ghanaian. Church worship and services were celebrated in manners that appealed more to Europeans than Africans. This therefore made many African Christians feel they did not belong to the European God. Ghanaians could not worship in purely traditional attire, prayers were recited in Latin, a language they did not understand, drumming and dancing associated with an African worldview of worship was not permitted. Thus, the natives of the Gold Coast (Ghana) nicknamed Christianity 'the white man's religion'. However, within the period of 1914-1937 some Africans began to find expression for the kind of Christianity contextualised in the African way of worship and spirituality. (p. 3)

The Pentecostal and Charismatic Churches have significantly impacted on the liturgy of HMCs leading to the introduction of some practices in their worship services such as clapping of hands, drumming and dancing, mass prayer, (hitherto, individuals prayed on behalf of the entire congregation, members prayed silently sitting and stood to sing), use of cymbals and tambourines, local choruses and sharing of testimonies (Atiemo 1993:38).

\section{Ministry}

The Pentecostal and Charismatic Churches encourage the development of individual gifts and talent for the general good of the Christian community. Each person is permitted to play his or her role in the general ministry of the church. Members belong to smaller groups in the church on which they depend for support and inspiration. They see themselves as a family by sharing in times of joy or sorrow, thereby reducing loneliness and fostering communal life amongst Christians (Atiemo 1993:40).

\section{Christian education}

Several theological questions, such as infant baptism, communion, divorce and marriage have been raised by PCCs. Effective Christian nurturing of members are pursued through bible studies, retreats, conferences and other religious programmes to teach members to be grounded in the Word of God. As a response, many other churches have embarked on bible studies in their churches. Consequently, most Christians now know certain fundamental biblical and theological truths (Atiemo 1993:41). Camp meetings, Easter and Christmas conventions have been adopted by some HMCs.

\section{Impact on the Ghanaian Society}

Like their missionary counterparts, PCCs are providing institutions of higher learning such as Central University College of the International Central Gospel Church, Dominion University of Action Chapel International, Pentecost University College, amongst others (Anderson 2004:405-405).

Economically members have businesses that give employment to the Ghanaian populace. Scholarship schemes have been instituted by most of these churches to support needy but brilliant students in basic and tertiary institutions. For example, the ICGC has since its establishment in 1884, 
fashioned out a systematic programme to meet the social and economic needs of its members and the Ghanaian community in general. The Lighthouse Chapel International also has a programme code-named 'Remember the Poor' in which free medical consultation, free medication, payment of apprenticeship fees, as well as pension for the elderly at Korle-Gonno community is undertaken as part of their social responsibility (Oboh 2013:26-30).

\section{Challenges}

Notwithstanding the impact, Pentecostal and Charismatics have made on ecclesiastical and Ghanaian society, there are some negative ethical issues that have confronted them such as promiscuity, power abuse, financial misappropriation, superstition and the commercialisation of the gospel either as a commodity for sale for material gain or as an object of investment for personal aggrandisement. Factors leading to this include inadequate training, poor accountability and low level of ethical reflection (Quampah 2012:viii).

\section{Findings, analysis and recommendations}

This section of the article has three main divisions. The first part discusses the views of respondents in respect of the categories of people who migrate, identifiable 'push' and pull factors in HMCs and PCCs, respectively, and mitigating measures HMCs should adopt to reduce or prevent migration of members. The second part is an analysis based on the findings and the integration of the insights of other scholars, the researcher's thought and observation, whilst the final part recommends a pastoral and laity response to the phenomenon of migration.

Table 1 shows the categories of members who migrate from HMCs to PCCs churches.

This was affirmed by respondents who had migrated. A total of 10 respondents representing $5.26 \%$ were pastors, 5 (2.63\%) catechists, 7 (3.68\%) caretakers, 60 (31.58\%) Bible Study and Prayer Group (BSPG), 76 (40\%), youth, 22 (11.58\%) women and $10(5.26 \%)$ men.
Table 2 shows the views of respondents about 'push' factors existing in HMCs such as the attitude of members, leadership attitude, liturgical problem, use of spiritual gift, generational gap, conflict, ministry and training, church discipline welfare and doctrinal issues. A total of 13 respondents representing $6.84 \%$ were of the view that the attitude of members was one contributing factor leading to the migration of members. However, $12(6.32 \%)$ respondents indicated leadership attitude, $19(10 \%)$ respondents said it was a liturgical problem, whilst $10(5.6 \%)$ respondents thought it was leadership not allowing members to use their spiritual gifts in the church.

Five respondents (2.63\%), instead asserted that the generational gap existing between the older members and the youth in the church is a major cause of migration. On the other hand, 11 (5.8\%) respondents emphasised that conflict amongst members also contributes significantly to members migrating. Moreover, 8 (4.21\%) respondents pointed out that welfare issues were usually some of the contributing factors to people migrating. Nevertheless, church discipline was alluded to by $20(10.52 \%)$ as another cause of migration, 12 $(6.32 \%)$ doctrinal issues, whilst $80(42.11 \%)$ respondents agreeing to factors A to I (Table 1), including murky answers to important theological questions, failure to address the meaning and objective of the Christian community (Conner 2011:36-37) are 'push' factors that contribute to the migration of members from HMCs to PCCs.

Moreover, 'pull' factors in PCCs that attract members of HMCs include oral liturgy with emphasis on the immediate presence of God at the worship service enriched by dancing and clapping of hands, quality church music, testimonies, care (spiritual or material), zealousness, fellowship, immediate baptism of new converts, healing, prayer for specific issues that confront the daily lives of members (such as court cases, examinations, lost properties, successful marriages, childbirth and travelling abroad). In addition, efforts are made to emphasise on health and wealth, the use of the mass media, new network, rebranding, frequent conferences with international speakers that reinforces transnationalism, providing a total environment for members to realise their potential, spontaneity, exercise of spiritual

TABLE 1: Categories of people who migrate from Historic Mission Churches to Pentecostal and Charismatic Churches.

\begin{tabular}{|c|c|c|c|c|c|c|c|c|c|c|c|c|c|c|c|c|}
\hline \multirow[t]{2}{*}{ Presbyteries } & \multicolumn{2}{|c|}{ Pastors } & \multicolumn{2}{|c|}{ Catechists } & \multicolumn{2}{|c|}{ Caretakers } & \multicolumn{2}{|c|}{ BSPG } & \multicolumn{2}{|c|}{ Youth } & \multicolumn{2}{|c|}{ Women } & \multicolumn{2}{|c|}{ Men } & \multicolumn{2}{|c|}{ Total } \\
\hline & $n$ & $\%$ & $n$ & $\%$ & $n$ & $\%$ & $n$ & $\%$ & $n$ & $\%$ & $n$ & $\%$ & $n$ & $\%$ & $n$ & $\%$ \\
\hline Ga & 6 & 3.16 & 3 & 1.58 & 5 & 2.63 & 29 & 15.26 & 41 & 21.58 & 10 & 5.26 & 6 & 3.16 & 100 & 52.63 \\
\hline Dangme-Tongu & 4 & 2.10 & 2 & 1.05 & 2 & 1.05 & 31 & 16.32 & 35 & 18.42 & 12 & 6.32 & 4 & 2.10 & 90 & 35.25 \\
\hline Total & 10 & 5.26 & 5 & 2.63 & 7 & 3.68 & 60 & 31.58 & 76 & 40.00 & 22 & 11.58 & 10 & 5.26 & 190 & 100.00 \\
\hline
\end{tabular}

BSPG, Bible Study and Prayer Group.

TABLE 2: Respondents' views about factors contributing to the migration of members from Historic Mission Churches to Pentecostal Churches.

\begin{tabular}{|c|c|c|c|c|c|c|c|c|c|c|c|c|c|c|c|c|c|c|c|c|c|c|}
\hline \multirow[t]{2}{*}{ Presbyteries } & \multicolumn{2}{|c|}{$\begin{array}{l}\text { Attitude of } \\
\text { members } \\
\text { (A) }\end{array}$} & \multicolumn{2}{|c|}{$\begin{array}{l}\text { Leadership } \\
\text { factor (B) }\end{array}$} & \multicolumn{2}{|c|}{$\begin{array}{l}\text { Liturgical } \\
\text { Problem } \\
\text { (C) }\end{array}$} & \multicolumn{2}{|c|}{$\begin{array}{l}\text { Use of } \\
\text { Spiritual } \\
\text { gift (D) }\end{array}$} & \multicolumn{2}{|c|}{$\begin{array}{l}\text { Generational } \\
\text { gap (E) }\end{array}$} & \multicolumn{2}{|c|}{$\begin{array}{l}\text { Conflict } \\
\text { (F) }\end{array}$} & \multicolumn{2}{|c|}{$\begin{array}{c}\text { Welfare } \\
\text { issues (G) }\end{array}$} & \multicolumn{2}{|c|}{$\begin{array}{l}\text { Church } \\
\text { discipline } \\
\text { (H) }\end{array}$} & \multicolumn{2}{|c|}{$\begin{array}{l}\text { Doctrinal } \\
\text { issues (I) }\end{array}$} & \multicolumn{2}{|c|}{$\begin{array}{c}\text { All the } \\
\text { above }(J) \dagger\end{array}$} & \multicolumn{2}{|c|}{ Total } \\
\hline & $n$ & $\%$ & $n$ & $\%$ & $n$ & $\%$ & $n$ & $\%$ & $n$ & $\%$ & $n$ & $\%$ & $n$ & $\%$ & $n$ & $\%$ & $n$ & $\%$ & $n$ & $\%$ & $n$ & $\%$ \\
\hline Ga & 8 & 4.21 & 8 & 4.21 & 11 & 5.79 & 5 & 2.63 & 3 & 1.58 & 4 & 2.11 & 5 & 2.63 & 13 & 6.84 & 9 & 4.74 & 34 & 17.89 & 100 & 52.63 \\
\hline Dangme-Tongu & 5 & 2.63 & 4 & 2.11 & 8 & 4.21 & 5 & 2.63 & 2 & 1.05 & 7 & 3.69 & 3 & 1.58 & 7 & 3.68 & 3 & 1.58 & 46 & 24.21 & 90 & 47.37 \\
\hline Total & 13 & 6.84 & 12 & 6.32 & 19 & 10.00 & 10 & 5.26 & 5 & 2.63 & 11 & 5.80 & 8 & 4.21 & 20 & 10.52 & 12 & 6.32 & 80 & 42.11 & 190 & 100.00 \\
\hline
\end{tabular}

$\dagger$, Respondents agree with the factors mentioned from A-I as the contributing factors. 
gifts, speaking in tongues and the interpretation of dreams (Asamoah-Gyadu 2013:xiii; Kim 2009:100-101).

The research also sought to find out mitigating measures HMCs could adopt to stop or reduce the migration of members to PCCs.

Table 3 shows varied views of respondents on some mitigating measures to be adopted by HMCs prevent or reduce members from migrating to PCCs.

From the given table, $5.26 \%$ of the respondents were of the view that attending to the spiritual needs of members is one mitigating measure the HMCs should adopt. According to $6.84 \%$ of the respondents, there is the need to attend to the welfare needs of members. A total of $11.05 \%$ alluded to the fact that timely resolution of conflict amongst members will prevent or reduce migration of members whilst $11.58 \%$ of the respondents, observed that it is important for HMCs to attend to the needs of all the different generations in the church. Counselling of members who have been disciplined, according to $8.95 \%$ of respondents, is a necessary mitigating measure the church must adopt. On the other hand, 14.74\% of respondents identified visitation of members as key to reducing or preventing members from migrating.

On the other hand, $70(36.84 \%)$ respondents indicated that for the HMCs to experience consistent growth without members migrating to PCCs, HMCs must attend to the spiritual welfare and generational needs of members. In addition, timely resolution of conflict amongst members, counselling of members who have been disciplined for one reason or the other as well as the visitation of members will go a long way in mitigating the issue of migration of members.

\section{The impact of migration of members on Presbyterian Church of Ghana}

Table 4 gives a vivid account of their responses.

The views of respondents regarding the specific effects of migration on the PCG were also verified by the researcher.
A total of 15 respondents representing 7.89\% expressed concern that the impact of migration on PCG is low membership. Also, 41 (21.58\%) indicated a loss of membership, whilst 29 of the total sample representing $15.26 \%$, identified low financial standing as the effect, however, 105 respondents representing 55.26\% identified low membership, loss of human resources and low financial standing as the impact of migration on PCG.

Most respondents pointed out that migration of members from PCG to PCCs gives credence to the general notion that members who migrate are in search of churches where they can experience the presence and move of the Holy Spirit.

\section{Analysis of findings}

Stott (2008:176-179) described the church as a redeemed Christian community of service distinct from the world in its convictions and values. Thus, the church is made up of different people from different cultures, experiences and backgrounds. However, for Christ, all members are equal, there is neither Greek nor Jew (Col. 3:10-11), rich or poor. Hence, there should be no barriers with regard to social standing, nationality, gender, race, education, wealth, religion or power.

Fellowship and care were demonstrated amongst the early Christians - all the believers met at one place and shared everything they had (Acts 2:44-45). At the core of the Christian life is human fellowship, which completes Christ's work on earth. Without shared fellowship, there can be no shared mission (Conner 2011:38-39; Flemming 2013:122-123, 153).

Church leadership, according to Niemandt (2019a:63, 67), is a gift of the Holy Spirit, an extension of Jesus' authority, thus, must be used to benefit the Christian community through trust, dependence on God, submission, worship and service. Leadership is also about creating possibilities and taking people along (Moynagh \& Harrold 2012:372-373).

The church is and should be a living and a growing 'organism', which continues to grow with new frontiers being pushed to

TABLE 3: Respondents' views on what could be done to stop or reduce the migration of members from Presbyterian Church of Ghana to Pentecostal and Charismatic Churches.

\begin{tabular}{|c|c|c|c|c|c|c|c|c|c|c|c|c|c|c|c|c|c|c|}
\hline \multirow[t]{2}{*}{ Presbyteries } & \multicolumn{2}{|c|}{$\begin{array}{l}\text { Improved } \\
\text { liturgy }\end{array}$} & \multicolumn{2}{|c|}{$\begin{array}{l}\text { Attend to the } \\
\text { spiritual needs } \\
\text { of members }\end{array}$} & \multicolumn{2}{|c|}{$\begin{array}{l}\text { Attend to the } \\
\text { welfare needs of } \\
\text { members }\end{array}$} & \multicolumn{2}{|c|}{$\begin{array}{l}\text { Timely } \\
\text { resolution of } \\
\text { conflicts }\end{array}$} & \multicolumn{2}{|c|}{$\begin{array}{l}\text { Attend to the } \\
\text { needs of all } \\
\text { generations }\end{array}$} & \multicolumn{2}{|c|}{$\begin{array}{c}\text { Counselling of } \\
\text { disciplined } \\
\text { members }\end{array}$} & \multicolumn{2}{|c|}{$\begin{array}{l}\text { Visitation of } \\
\text { members }\end{array}$} & \multicolumn{2}{|c|}{$\begin{array}{l}\text { All of the } \\
\text { above }\end{array}$} & \multicolumn{2}{|c|}{ Total } \\
\hline & $n$ & $\%$ & $n$ & $\%$ & $n$ & $\%$ & $n$ & $\%$ & $n$ & $\%$ & $n$ & $\%$ & $n$ & $\%$ & $n$ & $\%$ & $n$ & $\%$ \\
\hline Dangme-Tongu & 3 & 1.58 & 4 & 2.10 & 5 & 2.63 & 9 & 4.74 & 10 & 5.26 & 6 & 3.16 & 15 & 7.90 & 38 & 19.99 & 90 & 47.36 \\
\hline Total & 9 & 4.74 & 10 & 5.26 & 13 & 6.84 & 21 & 11.05 & 22 & 11.58 & 17 & 8.95 & 28 & 14.74 & 70 & 36.84 & 190 & 100 \\
\hline
\end{tabular}

TABLE 4: Respondents' views on the impact of migration on Presbyterian Church of Ghana.

\begin{tabular}{|c|c|c|c|c|c|c|c|c|c|c|}
\hline \multirow[t]{2}{*}{ Presbyteries } & \multicolumn{2}{|c|}{ Low membership } & \multicolumn{2}{|c|}{ Loss of Human resources } & \multicolumn{2}{|c|}{ Low financial standing } & \multicolumn{2}{|c|}{ All of the above $\uparrow$} & \multicolumn{2}{|c|}{ Total } \\
\hline & $n$ & $\%$ & $n$ & $\%$ & $n$ & $\%$ & $n$ & $\%$ & $n$ & $\%$ \\
\hline $\mathrm{Ga}$ & 9 & 4.73 & 17 & 8.95 & 11 & 5.79 & 63 & 33.16 & 100 & 52.63 \\
\hline Dangme-Tongu & 6 & 3.16 & 24 & 12.63 & 18 & 9.47 & 42 & 22.10 & 90 & 47.36 \\
\hline Total & 15 & 7.89 & 41 & 21.58 & 29 & 15.26 & 105 & 55.26 & 190 & 100 \\
\hline
\end{tabular}

$\dagger$, Respondents agree with the factors mentioned contributing factors listed in Table 4. 
the ends of the earth, hence, Jesus Christ is still calling people into ministry through the church in the power of the Holy Spirit. In this regard, church members who have been identified to be spiritually gifted and affirmed by spiritual leaders must be guided and trained to be effective tools in the hands of God and motivated for mission (Cousins \& Judson 1984:19, 23; Moynagh \& Harrold 2012:395-397).

Different generations shall continue to exist in every church; however, the response mechanisms put in place to meet their different needs in a church or denomination shall determine how far that church will grow. Anderson also asserts that the Pentecostal and Charismatics can tap into the ancient religious traditions whilst mixing it with the modern, hence, appealing to people who belong to both worlds (Asamoah-Gyadu 2013:xiii)

According to Warren $(1995: 32,48)$, the health of a church is measured by its sending capacity. Thus, the church should train and send out the laity to become the active component in the church. It has been observed that an over concentration on clergy without the involvement of the laity would cause the clergy to focus more on maintaining the church to the neglect of others outside the church (Moynagh \& Harrold 2012:78, 80). In this regard, gifted members must be grouped into ministries so that they can develop fellowship amongst themselves.

For the church to impact the world, it must go beyond verbal witness and spirituality to meet the needs of people in the church and society. However, the needs of the people must not be isolated from the message of the gospel (Flemming 2013:12, 14, 105, 107; Ott et al. 2010:99).

The church's loss of members correlates with the feeling that the church had abandoned them in matters of church discipline and life transitions such as birth, marriage, divorce, retirement and bereavement. Ministers of the gospel should endeavour to walk with people and listen to their stories (Flemming 2013:108-109). In the light of the church being called to address the private and public life of people in a community, there is the need to have a ministerial training in tandem with the demand of the gospel (Newbigin 1989:230-236).

Arguments for or against infant baptism are both biblical and theological. Whilst advocates for infant baptism argue that baptism is an initiation into the community of faith, others are of the opinion that becoming a Christian involves repentance, assurance of salvation, faith and receiving the Holy Spirit, therefore, infants should not be baptised on this score (Moynagh \& Harrold 2012:359, 441). In the view of Mante (2008:10-13), the Evangelical and Reformed tradition believe in the original Adamic sin, thus, during baptism, one is sanctified and made holy by grace. Baptism also receives an individual into the family of Christ and the church. However, James $(2003: 5-6,13)$ refers to the great commission mandate (Matt. 28:19) that a disciple in this context means one who, eagerly learned Christ's teachings, confessed Christ before men, obeyed Christ's commands, denied himself in order to follow Christ, willing to die for Christ in the face of persecution.

\section{Recommendations}

Based on the research findings, the following recommendations (structural, pastoral and socioeconomic) are made hoping that it would help the PCG to mitigate the phenomenon of migration of members to PCCs.

\section{Structural issues}

All PCG congregations should establish new members or converts class in order to make such new members, disciples.

Also, PCG should give baptismal candidates the option to choose the type of baptism they prefer (sprinkling or immersion) after going through the stipulated baptismal class. Children who were baptised as infants must be given the opportunity at least from age 5 to be taught the doctrines of the church.

On the other hand, in order to ensure consistent growth pattern in PCG, all ministers on probation with the leading of the Holy Spirit, should be resourced and helped to plant at least one church within 2 years before they are ordained.

All PCG local congregations should form home cells, because it is impossible for the pastor alone to care for all members and offer them a close fellowship in the congregation.

There is the need to build a strong missional community in the PCG. Therefore, all PCG congregations should make discipleship and missional vocation a topmost priority.

In addition, PCG should profile all congregations and ministers. This should be done with a monitoring system in place to know how ministers and congregations are performing.

In order to bridge the existing generational gap, there is a need for youth services and youth pastors in all PCG congregations.

Presbyterian Church of Ghana should establish her own Seminary, where church planting and doctrines of the church can be effectively taught whilst the progress of people they have trained shall be monitored. This will help to reshape the curriculum if necessary.

\section{Pastoral issues}

The laity is the resources in God's mission through the church, hence, their gifts must be identified and trained to fulfil the desires of the church and community.

Gifted members in congregations must be grouped into ministries so that they can develop fellowship without competing amongst themselves. 
Ministers in the PCG, must see visitation as a ministry, hence, be accessible and available to members of his or her congregation and the community by paying regular visits.

\section{Socio-economic issues}

All PCG local congregations should be encouraged to establish income-generating projects to augment their income.

Besides, all children service and junior youth members in PCG should be taught Christian giving and made to pay tithes.

Presbyterian Church of Ghana should adopt a new system of assessment, which should include the number of new converts won, nurtured and disciplined and the impact of the congregation in its missional work in the community.

\section{Conclusion}

With the advent of PCCs in the early 20th century in the Ghanaian religious landscape, there is an observable trend of migration of members from HMCs to PCCs because of 'push' and 'pull' factors. This article argues that migration of members from HMCs to PCCs in Ghana is a reality, which over the years has led to slow growth in membership and human resource mobilisation in PCG.

The findings revealed some 'push' and 'pull' factors that induce members to migrate from HMCs to PCCs, respectively. Structural, pastoral and socio-economic responses that will help carve a new image for HMCs and for that matter the PCG as missional communities were recommended.

\section{Recommendation for future research}

This article did not explore whether those who migrated from HMCs to PCCs are coming back to the HMCs, this is yet to be explored. It is, therefore, recommended that researchers who may want to carry out further studies on migration should consider this aspect.

\section{Acknowledgements Competing interests}

The authors have declared that no competing interests exist.

\section{Authors' contributions}

E.S. carried out fieldwork, write-up, research and compilation of the manuscript. C.N. (research leader and supervisor) and P.W. (co-supervisor) were involved in conceptualisation, editing of research and final write-up of this article.

\section{Ethical consideration}

Permission to conduct the study was received from the Faculty of Theology and Religion, University of Pretoria.

\section{Funding information}

This research received no specific grant from any funding agency.

\section{Data availability statement}

Data sharing is not applicable to this article as no new data were created or analysed in this study.

\section{Disclaimer}

The views and opinions expressed in this article are those of the authors and do not necessarily reflect the official policy or position of any affiliated agency of the authors.

\section{References}

Anderson, A., 2004, An introduction to Pentecostalism, Cambridge University Press, Cambridge.

Asamoah-Gyadu, J.K., 1997, “"Missionaries without Robes”: Lay charismatic fellowships and the evangelization of Ghana, Pneuma', The Journal of the Society for Pentecostal Studies 19(2), 168. https://doi.org/10.1163/157007497 X00118

Asamoah-Gyadu, J.K., 2002, 'Pentecostalism in Africa and the changing face of Christian mission: Pentecostal/charismatic renewal movements in Ghana', Mission Studies 19(2), 17. https://doi.org/10.1163/157338302X00161

Asamoah-Gyadu, J.K., 2005a, African charismatics: Current development within independent indigenous Pentecostalism in Ghana, Koninklijke Brill N.V, Leiden.

Asamoah-Gyadu, J.K., 2005b, "'Signs of the spirit": Worship as experience in African Pentecostalism', Journal of African Christian Thought 8(2), 23.

Asamoah-Gyadu, J.K., 2013, Contemporary Pentecostal Christianity: Interpretations from an African context, Regnum Book International, Oxford.

Atiemo, A., 1993, The rise of charismatic movement in the mainline churches, Asempa Publishers, Accra.

Bediako, K., 1999, Theology and identity: The impact of culture upon Christian thought in the second century and in modern Africa, 2nd edn., Regnum Books International, Oxford.

Bosch, D.J., 1991, Transforming missions: Paradigm shift in theology of mission, Orbis Books, Maryknoll, New York, NY.

Conner, B.T., 2011, Practicing witness: A missional vision of Christian practices, Eerdmans Publication Company, Grand Rapids, MI.

Cousins, D. \& Judson, P., 1984, Building your church: Using your gifts, time, and resources, Zondervan Publication House, Illinois.

Deji, A. \& Ishola, S.A., 1999, African indigenous churches: An historical perspective, Reater Heights Publications, Lagos.

Foli, R., 2001, The church in Ghana today, Wesleyan Printing Press, Accra.

Flemming, D., 2013, Recovering the full mission of God: A Biblical perspective on being, doing and telling, Intervarsity Press, Downers Grove, IL.

Ga Presbytery, 2012, 90th anniversary brochure, pp. 7-8, Riis Press Ltd, Accra.

Hildebrandt, J., 1981, History of the church in Africa - A survey, African Christian Press, Accra.

James, J., 2003, Infant Baptism or believer's Baptism? Word of the Cross Publication, Garsfontein East.

Kim, K., 2009, Joining in with the spirit: Connecting world church and local mission, Epworth Press, Marylebone.

Kpobi, D.N.A., 1999, "Renewal and reformation": Ghanaian churches in mission in the 21st century', Trinity Journal of Church and Theology 9(2), 7.

Krejcir, R.J. \& Johnson, B., 2018, Statistics and reasons for church decline, viewed 16 August 2018, from http://www.churchleadership.org.

Mante, J.O.Y., 2008, Why baptize infants? Akwapem Presbytery Press, AkropongAkwapem.

Moynagh, M. \& Harrold, P., 2012, Church in every context: An introduction to theology and practice, SCM Press, Norwich.

Newbigin, L., 1989, The gospel in a pluralistic society, Eerdmans Publishing Company, Grand Rapids, MI.

Niemandt, N., 2019, 'How the church organises itself?', in Missional leadership, (HTS Religion and Society Series, vol. 7), pp. 55-68, AOSIS, Cape Town. https://doi. org/10.4102/aosis.2019.BK108

Omenyo, C.N., 2006, Pentecost outside Pentecostalism: A study of the development of charismatic renewal in the mainline churches in Ghana, Boekencentrum Publishing House, Zoetermeer. 
Oboh, C., 2013, 'Pentecostal/charismatic Christianity in an African Urban context: A historical and missiological study of the Full Gospel Church International 1978-2013', MTh dissertation, Trinity Theological Seminary, Accra.

Ott, C., Strauss, S. \& Tennent, T.C., 2010, Encountering Theology of Mission: Biblical Foundation and Contemporary Issues, Baker Publishing Group, Grand Rapids, Michigan.

Pobee, J.S. \& Ositelu II, G., 1998, African initiatives in Christianity: The growth, gifts and diversities of Indigenous African churches, a challenge to the ecumenical movements, WCC Publications, Geneva.

Presbyterian Church of Ghana (PCG), 2018, 'Statistics presented to the 19th General Assembly', by the Committee on Information Management, Statistics and Planning at Ramseyer Training Centre, Abetifi 16-22 August, 6-9, 33.

Presbyterian Church of Ghana (PCG), Dangme-Tongu Presbytery, 1972-2012, 40th anniversary brochure, 5,13 .

Quampah, D., 2012, 'The ethical dimension of Pentecostal/charismatic leadership in Ghana', PhD thesis, University of Ghana, Accra.
Sanneh, L., 2008, Disciples of all nations: Pillars of world Christianity, Oxford University Press, New York, NY.

Smith, N., 1966, The presbyterian church of Ghana, 1835-1960: A younger church in a changing society, Ghana Universities Press, Accra.

Stott, J., 2008, Christian mission in the modern world, Intervarsity Press, Downers Grove, IL.

Teevan, J. \& Hewitt, W.E. (ed.), 1998, Introduction to sociology: A Canadian focus, Prentice Hall, Ontario.

Warren, R., 1995, The purpose driven church: Growth without compromising your message and mission, Oasis International Ltd., Michigan.

White, P., 2017, 'Decolonising Western missionaries mission theology and practice in Ghanaian church history: A Pentecostal approach', In die Skriflig 51(1), a2233. https://doi.org/0.4102/ids.v51i1.2233.

White, P. \& Neimandt, C.P.J., 2015, 'Ghanaian Pentecostal churches' mission approaches', Journal of Pentecostal Theology 24(2), 250. https://doi.org/10.1163/17455251 02402010 